\title{
The Toxins of Clostridium oedematiens (Cl. novyi)
}

\author{
BY C. L. OAKLEY, G. HARRIET WARRACK AND \\ PATRICIA H. CLARKE
}

The Wellcome Physiological Research Laboratories, Beckenham, Kent

SUMMARY: Six antigenic components have been identifled in toxic filtrates from Clostridium oedematiens, which have been designated $\alpha, \beta, \gamma, \delta, \epsilon$ and $\zeta$.

$\alpha$ is the classical lethal toxin of $\mathrm{Cl}$. oedematiens and $\beta$ and $\gamma$ are haemolytic lecithinases, $\beta$ being certainly necrotizing; $\delta$ and $\zeta$ are haemolytic, $\delta$ being oxygen labile; and $\epsilon$ is probably responsible for pearly layer formation. Type A strains of Cl. oedematiens produce $\alpha, \gamma, \delta$ and $\epsilon$; type B strains $\alpha, \beta$ and $\zeta$; type $\mathbf{C}$ strains produce none of these components when examined by our methods. Two strains of $\mathrm{Cl}$. haemolyticum produced the $\beta$ lecithinase.

By methods based on certain characteristic properties of these six antigenic components, 'oedematiens' antisera can be tested for the corresponding antibodies.

In the identification of the various types of $\mathrm{Cl}$. oedematiens, methods based on the properties of the $\beta, \gamma$ and $\epsilon$ components give more consistent and clear-cut results than those depending on morphology, colonial formation or fermentation reactions.

In 1894 Novy described as Bacillus oedematis maligni no. 2 a Gram-positive obligate anaerobic bacillus isolated by him from guinea-pigs inoculated with milk nuclein; this account is generally regarded as the first reference to the organism now known as Clostridium oedematiens (Cl. novyi, Bergey, Breed, Murray \& Hitchen, 1939). Novy showed that injection of pure cultures of the organism led to death of experimental animals, and observing that death was not necessarily associated with evidence of local or general growth of the organism, concluded that death was due to injected toxic products. Since that time numerous accounts have appeared of organisms related to Bacillus oedematis maligni no. 2. In 1934. Scott, Turner \& Vawter divided them into three groups as shown in Table 1.

\section{Products detected in culture filtrates}

The lethal toxin. Filtrates from $\mathrm{Cl}$. oedematiens type $\mathbf{A}$ and type $\mathbf{B}$ often contain a lethal toxin, which is thermolabile (Zeissler \& Rassfeld, 1929), produces on injection into animals the gelatinous pink-stained oedema of connective tissue and muscle characteristic of $\mathrm{Cl}$. oedematiens infections (Weinberg \& Séguin, 1915a,b, c; Menk, 1981/2), produces a local lesion in the rabbit cornea (Gildemeister \& Schlossberger, 1932) and is readily neutralized by anti-oedematiens sera produced in animals by injection of either type A or type B filtrates (Turner \& Davesne, 1927 $a, b$ ). All these activities are ascribed, probably correctly, though on little evidence, to a single lethal toxin; methods for its routine production were given by Walbum \& Reymann (1937).

Haemolysins. Both $\mathrm{Cl}$. oedematiens type A (Menk, 1931/2; Celarek \& Stetkiewicz, 1936; Reed, Orr \& Baker, 1939) and type B (Turner \& Davesne, 1927 b; MacEwen, 1931) produce haemolysins, and the literature contains evidence that some of these are distinct from the lethal toxin and that the type $A$ haemolysin complex is different from that produced by type B. Glotowa, Ostrowskaya, Ssilanowa \& Milaschewskaya (1934) found poor agreement between lethal and haemolytic values for sera against $\mathrm{Cl}$. oedematiens filtrates. Reed \& Orr (1941) state that for the most part haemotoxins 
as well as lethal toxins of the pathogenic species of Clostridium are species-specific, but give no evidence to support this view. Keppie (1944) showed that type $A$ antisera failed to neutralize the haemolysin of $\mathrm{Cl}$. oedematiens type $\mathrm{B}$ filtrates, but did not determine whether this was dependent on their strength, or whether the haemolysins were antigenically distinct. Hayward \& Gray (1946), devising an empirical haemolysin test to differentiate between $\mathrm{Cl}$. oedematiens and $\mathrm{Cl}$. septicum, found that sera neutralizing the haemolysins of $\mathrm{Cl}$. oedematiens (type A) failed to neutralize those of Bacillus gigas (Cl. oedematiens type B).

Table 1. Classification of Cl. oedematiens (Scott et al. 1934)

\begin{tabular}{|c|c|c|c|c|c|c|}
\hline Type & Organisms included & Origin & Size & $\begin{array}{l}\text { Fermenta- } \\
\text { tion of } \\
\text { glycerol }\end{array}$ & $\begin{array}{l}\text { Experi- } \\
\text { mental } \\
\text { patho- } \\
\text { genicity }\end{array}$ & $\begin{array}{l}\text { Toxi- } \\
\text { genicity }\end{array}$ \\
\hline $\mathbf{A}$ & $\begin{array}{l}\text { B. oedematis maligni no. } 2 \\
\text { (Novy, 1894) } \\
\text { B. oedematiens (Weinberg \& } \\
\text { Séguin, 1915b) } \\
\text { Cl. oedematiens } \\
\text { Cl. novyi }\end{array}$ & $\begin{array}{l}\text { Gas gangrene } \\
\text { of man and } \\
\text { other animals }\end{array}$ & $\begin{array}{l}\text { Small } \\
0 \cdot 8-1 \times \\
2 \cdot 5-5 \mu\end{array}$ & + & + & + \\
\hline $\mathbf{B}$ & $\begin{array}{l}\text { B. oedematiens (Albiston, } \\
\text { 1927; Turner \& Davesne, } \\
\text { 1927 a,b) } \\
\text { B. gigas (Zeissler \& Rassfeld, } \\
\text { 1929) }\end{array}$ & $\begin{array}{l}\text { Black disease } \\
\text { and Bradsot } \\
\text { of sheep }\end{array}$ & $\begin{array}{l}\text { Large } \\
1 \cdot 2-2 \times \\
10-14 \mu\end{array}$ & - & + & + \\
\hline $\mathbf{C}$ & $\begin{array}{l}\text { Bacillus of osteomyelitis } \\
\text { bacillosa bubalorum } \\
\text { (Kranefeld \& Djaenoedin, } \\
\text { 1933, 1936) }\end{array}$ & $\begin{array}{l}\text { Bacillary } \\
\text { osteomyelitis } \\
\text { of buffaloes }\end{array}$ & $\begin{array}{l}\text { Large } \\
1 \cdot 5-2 \times \\
8-10 \mu\end{array}$ & - & - & - \\
\hline
\end{tabular}

Substances affecting egg-yolk emulsion (lecitho-vitellin, L.V.). Crook (1942) claimed that many strains of $\mathrm{Cl}$. oedematiens produced opalescence in egg-yolk emulsion (see Macfarlane, R. G., Oakley \& Anderson, 1941) and that some strains produced as intense an opalescence as that due to filtrates of $\mathrm{Cl}$. welchii type A. Macfarlane, M. G. (1942) stated that some $\mathrm{Cl}$. oedematiens filtrates (probably derived from the type $\mathrm{B}$ strain 'Albiston') contained a weak lecithinase antigenically distinct from the lethal toxin and from the lecithinase ( $\alpha$-toxin) of $\mathrm{Cl}$. welchii. Small amounts of a lecithinase are extractable from the tissues of animals infected with $\mathrm{Cl}$. oedematiens (type not stated; McClean, Rogers, Williams \& Hale, 1943). Nagler (1945) states that neutralization tests on plates show that the substances diffusing from $\mathrm{Cl}$. oedematiens colonies and producing opalescence on egg-yolk agar and haemolysis on sheep-blood agar are probably identical.

The substance producing the 'pearly layer'. Nagler $(1944,1945)$ has shown that the surface of colonies of $\mathrm{Cl}$. oedematiens type A growing on egg-yolk sheep-blood agar is covered by a 'pearly layer' easily detachable from the surface, and that types $B$ and C do not produce this effect. The substance giving rise to this effect is rather labile, thermolabile, and was not neutralized by two anti-oedematiens sera tested: McClung, Heidenreich \& Toabe (1946) have claimed that $\mathrm{Cl}$. oedematiens type $\mathrm{A}$ can be distinguished from type B and from $\mathrm{Cl}$. sordellii and $\mathrm{Cl}$. perfringens by the 'reactions' produced on a medium containing $4 \%$ proteose-peptone, glucose, egg yolk and defibrinated rabbit blood; these reactions are said to be distinct and to be inhibited by 'appropriate' sera; it is stated that the blood may be omitted. No other details are given.

Hyaluronidase. Of fifteen strains of $\mathrm{Cl}$. oedematiens examined by McClean et al. (1943) only seven produced measurable amounts of hyaluronidase; Keppie's thesis (1944) shows that these were all type B strains. 
In the present paper evidence is offered for the existence in $\mathrm{Cl}$. oedematiens filtrates of at least six antigenic substances, by the use of which, and of suitable neutralizing sera, it is easy to distinguish between $\mathrm{Cl}$. oedematiens types $\mathbf{A}$ and $B$ and other anaerobes.

\section{EXPERIMENTAL}

\section{Material and methods}

Strains. We used 103 strains of Clostridium, either described by other workers as $\mathrm{Cl}$. oedematiens, $\mathrm{Cl}$. novyi or $\mathrm{B}$. gigas, or regarded by them as more closely related to these organisms than to any other Clostridium so far described. All these were compared and as far as possible classified on a basis of morphology, colony form, fermentation reactions and toxin production.

The type A strains were of the usual origin: two from gas gangrene in animals, forty-three from gas gangrene in man, including the classical strains 'Cossard', 'Domange', 'Jolly', and ' $B$ 140' from the 1914-18 war, and thirtynine from various battle-fronts (three from Germany), including air-raid casualties in the war of 1989-45.

Of the sixteen type B strains twelve were derived from sheep, five from cases of Black disease in Australia, three from England and four from Germany. The remaining four were isolated from man, three from mixed infections; the fourth was the only organism recovered from a typical fatal case of gas gangrene (MacLennan, unpublished).

Only two type $\mathrm{C}$ strains were available.

Cultural methods. Cultures were grown for toxin production on the medium used for routine production of lethal toxin. Before 1943 this was Wright's broth prefermented with Aerobacter aerogenes; since then the medium has been a papain digest of horse meat (total $\mathrm{N} \mathrm{6-7}$ g./1.) to which was added $10 \%$ of a sat. sodium sulphate solution extract of horse muscle (Macfarlane \& Knight, 1941). Sodium thiolacetate or sodium 'hydrosulphite' (dithionite) was added to ensure anaerobic conditions. Cultures were grown in 1 or 41 . bottles, occasionally in smaller volumes; bacteria were removed from the culture fluid either by centrifugation or by filtration through paper after mixing with 'Hyflo-supercel' (Johns-Manville, Ltd., 5 g./l.). When required sterile a filtrate was refiltered through Berkefeld filters, or through Seitz sterilizing pads, filtering at least $30 \mathrm{ml} . / \mathrm{sq} . \mathrm{cm}$. of the pad.

For some purposes filtrates were precipitated by saturation with ammonium sulphate and the precipitate dried in vacuo over silica gel or dialysed overnight against tap water. If the dried precipitate contained too much ammonium sulphate for easy use, the powdered material was stirred up with dry chloroform; much of the ammonium sulphate sank to the bottom, and the floating 'toxin' was skimmed off and dried.

Sera. We examined forty sera, obtained at all stages of immunization from horses hyperimmunized against $\mathrm{Cl}$. oedematiens. Of all these sera the antilethal values (i.e. the values obtained by subcutaneous injection of lethaltoxin-antitoxin mixtures into mice) were accurately known. 
The general method of titration has been to devise indicators of toxic activity, choose arbitrary standard sera active against filtrates affecting these indicators, and to estimate the values of other sera against these standards. To do this the test dose of filtrate was determined as that amount of filtrate which, when mixed with a convenient volume of standard serum (arbitrarily called $x$ units), allowed to stand for an appropriate time and added to the indicator, produced a standard indicating effect. The values of sera were then determined by estimating the amount of serum required to neutralize the test dose of filtrate to the point at which it just produced the standard indicating effect on the indicator. Such a mixture contains $x$ units of antitoxin; from this information the value of any serum is readily derived. All filtrates were also examined by flocculation and by animal tests for the classical lethal toxin.

\section{EXAMINATION OF FILTRATES FOR TOXINS}

\section{Lecitho-vitellin (L.V.) tests}

Level of testing three units; diluent $\mathrm{M} / 5$-sodium acetate-acetic acid to pH 6.5 (=S.A.B.); allow mixture to stand $\frac{1}{2} \mathrm{hr}$, add $0.5 \mathrm{ml}$. L.V. (Macfarlane, R. G. et al. 1941) as indicator, place tests in water bath at $37^{\circ}$ for $1 \mathrm{hr}$., read following morning; slight opalescence was taken as the indicating effect.

The toxic filtrates from $\mathrm{Cl}$. oedematiens type $\mathrm{A}$ available to us when we began this work readily produced opalescence in egg-yolk emulsions (L.V.); we therefore chose serum R7903 as standard, gave it a value of 1700 units and determined the values of our other sera against six different type A filtrates. Strictly speaking R7903 and Ex949 (see p. 97) are secondary standards, the values of which are given in terms of our original arbitrary standards, now exhausted. Table 2 shows the results obtained from a representative selection of the sera.

Table 2. Comparison of anti-lethal values of anti-oedematiens sera with lecithovitellin values against several different $\mathrm{Cl}$. oedematiens type $A$ filtrates

\begin{tabular}{|c|c|c|c|c|c|}
\hline \multirow[b]{2}{*}{ Serum } & \multirow{2}{*}{$\begin{array}{l}\text { Anti-lethal } \\
\text { value }\end{array}$} & \multicolumn{4}{|c|}{ Lecitho-vitellin value against filtrate } \\
\hline & & AE51 & AE 208 & AE327 & OC 19345 \\
\hline R7903* & 950 & 1700 & 1700 & 1700 & 1700 \\
\hline 9517 & 1700 & 800 & 800 & 900 & 700 \\
\hline 9783 & 1000 & 740 & 660 & 1100 & 700 \\
\hline 202 & 800 & 670 & 580 & 700 & 750 \\
\hline 644 & 800 & 630 & 630 & 800 & 500 \\
\hline $\mathbf{R 7 5 4 8}$ & $\mathbf{5 5 0}$ & 270 & 270 & 270 & 160 \\
\hline 171 & $1 \cdot 7$ & 290 & 240 & 250 & - \\
\hline
\end{tabular}

Two conclusions can be drawn from Table 2. First, that whatever L.V. values are chosen for comparison, they bear no relationship whatever to the anti-lethal values; it is probable therefore that whatever is producing opalescence in $L . V$. is not the lethal toxin, a view which is supported by the fact that $\mathrm{Cl}$. oedematiens filtrates capable of producing dense opalescence in L.V. may 
show no lethal activity. Secondly, though the L.V. values of sera agree fairly well among themselves, there are occasional very large discrepancies (cf. values of R7548 for instance). Such discrepancies are most readily explained by the existence in the filtrates of varying proportions of more than one substance affecting the indicator (egg-yolk emulsion).

\section{Haemolytic tests}

Level of testing 1-3 units; diluent S.A.B.; allow mixtures to stand $\frac{1}{2} \mathrm{hr}$., add $0.5 \mathrm{ml}$. $6 \%$ washed horse red cells in saline, place tests in water bath at $37^{\circ}$ for $1 \mathrm{hr}$., examine on removal from bath, and not less than $2 \mathrm{hr}$. thereafter. Indicating effect $20 \%$ haemolysis. Rabbit cells may be used; sheep cells are rather insensitive.

Table 3. Comparison of haemolytic and lecitho-vitellin values of sera against two different $\mathrm{Cl}$. oedematiens type $A$ filtrates

\begin{tabular}{|c|c|c|c|c|}
\hline \multirow[b]{2}{*}{ Serum } & \multicolumn{2}{|c|}{$\begin{array}{c}\text { Haemolytic } \\
\text { values against }\end{array}$} & \multicolumn{2}{|c|}{$\begin{array}{l}\text { Lecitho-vitellin } \\
\text { values against }\end{array}$} \\
\hline & AE 327 & OC19345 & AE327 & OC 19345 \\
\hline R7903 & 1700 & 1700 & 1700 & 1700 \\
\hline 202 & 650 & 800 & 700 & 750 \\
\hline $850 B$ & 650 & 800 & 300 & 160 \\
\hline 644 & $\mathbf{9 5 0}$ & 850 & 800 & 500 \\
\hline 9783 & 1100 & 1100 & 1100 & 700 \\
\hline 171 & 1800 & - & 250 & - \\
\hline
\end{tabular}

Haemolytic tests using the same standard filtrates and sera (Table 3) support the view that two independent antigens are present, for though for both the filtrates shown the haemolytic and L.V. values of some of the sera (e.g. 202) agree, for others the L.V. value against one or other filtrate is lower than the haemolytic value. The haemolytic values against all the filtrates showed good agreement, suggesting that only one haemolytic substance was present. Moreover, when the L.V. value differs from the haemolytic value, the L.V. values using different filtrates show some indication of being in proportion; thus for sera 644, 9783, 850B the L.V. values against filtrate OC19345 are about half those against filtrate AE327. We therefore conclude that the type A filtrates examined by us contained two substances distinct from the lethal toxin $(\alpha)$, one causing opalescence and haemolysis $(\gamma)$, the other opalescence only $(\epsilon)$.

Further evidence in favour of this view was obtained from partial neutralization tests; for instance if a filtrate were partially neutralized with a serum whose L.V. value was much lower than its haemolytic value (i.e. a serum containing as compared with the standard proportionately more $\gamma$-antitoxin than $\epsilon$-antitoxin) it might be expected that titratable $\epsilon$ would remain after all the $\gamma$ had been neutralized, and that using the partially neutralized mixture as test toxin, L.V. tests would give the L.V. value for sera when it was lower than the haemolytic value (using a serum like 171 as standard) and a value higher than either when the haemolytic and L.V. values were equal. Though these expectations have on the whole been fulfilled, practical difficulties due to the 
poor neutralizing power of our sera, and the small number of indicating doses of $\epsilon$ present in most filtrates, make the results rather unreliable.

Another method of testing the independence of $\gamma$ and $\epsilon$ has been derived from the experiments of Nagler (1944, 1945), who showed that if $\mathrm{Cl}$. oedematiens type A was grown on egg-yolk sheep-blood agar plates a pearly layer was formed on the surface of the colony. We had found (like McClung et al. 1946) that the blood could be omitted from the medium; when this was done, not only could the pearly layer be seen at the surface, but another more diffuse opalescence could be seen below it. When blood is included in the medium, a

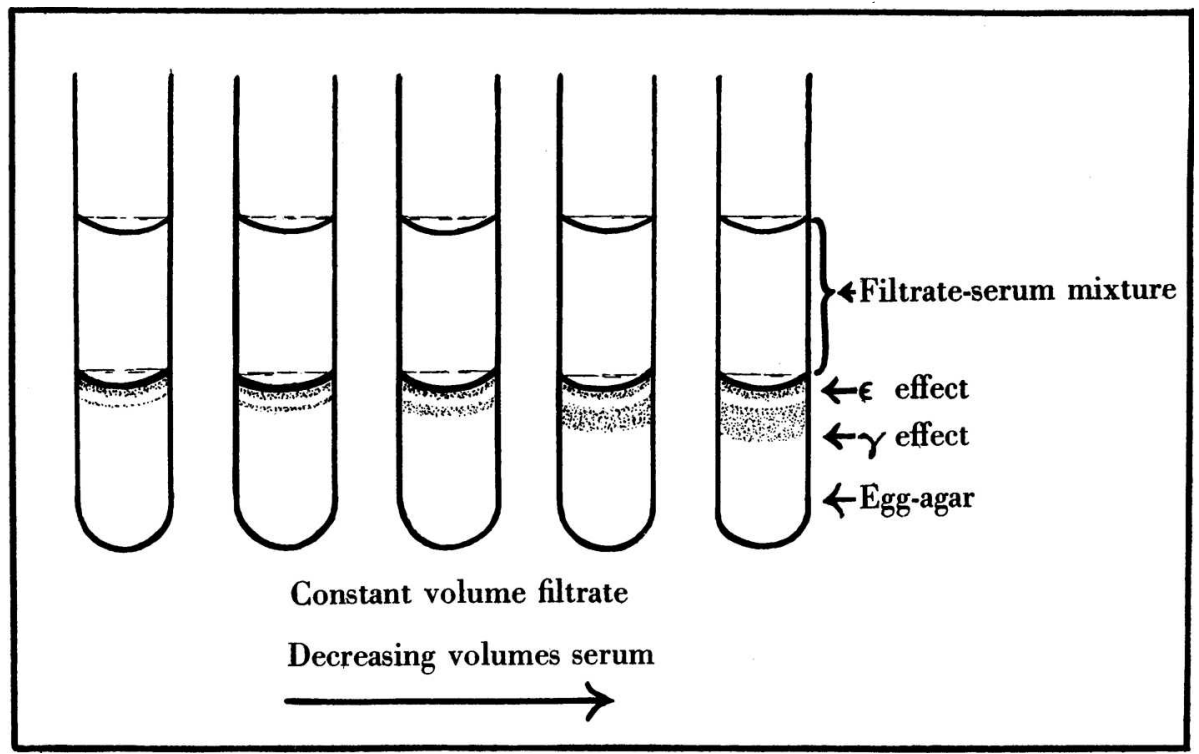

Text-fig. 1. The egg-agar test.

haemolytic zone of roughly the same extent as the diffuse opalescence is formed round the colony. All these observations raised our hopes that the pearly layer might be due to $\epsilon$, and the diffuse opalescence and haemolysis to $\gamma$. If this were true we might be able to achieve physical separation of the $\gamma$ and $\epsilon$ effects in L.V. tests. We therefore devised the egg-agar test (Text-fig. 1).

Filtrate serum mixtures are made in the usual way, allowed to stand $\frac{1}{2} \mathrm{hr}$., then poured on the top of a column of Weinberg's V.F. agar containing about $5 \%$ of L.V., and the whole incubated in the water-bath at $37^{\circ}$ for $18-24 \mathrm{hr}$. If the filtrate-serum mixture is under-neutralized two distinct effects are produced in the agar: at the surface a dense opalescence, and deeper in the medium and separated from the surface opalescence by a comparatively clear zone, a faintly opalescent ring. If the latter opalescent ring is used as indicator in serumtitration tests, 'egg-agar' values can be obtained for sera; and these (as Table 4 shows) agree with the haemolytic values whether the L.V. values agree with them or not. There is therefore considerable evidence that $\gamma$ is haemolytic and opalescence-forming, as distinct from $\epsilon$, which causes only 
opalescence. Attempts to carry out anti- $\epsilon$ tests on sera, using the surface opalescence as indicator either in tubes or on egg-agar plates, have been successful only on occasion, as the end-point of such titrations is far too uncertain for accuracy.

Table 4. Comparison of lecitho-vitellin, haemolytic and egg-agar values of sera against the same Cl. oedematiens type A filtrate (OC19345)

\begin{tabular}{cccc} 
& \multicolumn{3}{c}{ Indicator } \\
\cline { 2 - 4 } Serum & Lecitho-vitellin & Red cells & Egg agar \\
R7903 & 1700 & 1700 & 1700 \\
R7548 & 160 & 300 & 310 \\
850 B & 160 & 800 & 900 \\
9559 & 350 & 400 & 400 \\
644 & 500 & 850 & 850 \\
645 & 500 & 800 & 750 \\
9783 & 700 & 1100 & 1200 \\
202 & 750 & 800 & 800
\end{tabular}

Type A filtrates from some cultures in peptic digest media contain little $\gamma$ as judged by L.V. tests; they may, however, be vigorously haemolytic. $\gamma$-, like the $\alpha$-toxin of $\mathrm{Cl}$. welchii, is a hot-cold haemolysin; filtrates from peptic digests may haemolyse almost immediately at $37^{\circ}$. The haemolysin $(\delta)$ is oxygenlabile, and is to some extent neutralized by heterologous sera. As Table 1 shows, serum values against this haemolysin (diluent phosphate buffer $\mathrm{pH}$ $6.5+M / 25$-sodium thiolacetate, indicator $0.5 \mathrm{ml} .6 \%$ washed horse cells in saline) show no relationship to the $\alpha, \gamma$ or $\epsilon$ values; $\delta$ is therefore probably distinct from $\alpha$-, $\gamma$ - and $\epsilon$-toxins.

Table 5. Comparison of anti- $\delta$ with other values of sera, to show independence of $\delta$-toxin

$\begin{array}{rcccc}\text { Serum } & \text { Anti- } \alpha \text { value } & \text { Anti- } \boldsymbol{\gamma} \text { value } & \text { Anti- } \epsilon \text { value } & \text { Anti- } \delta \text { value } \\ \text { R7548 } & \mathbf{5 5 0} & \mathbf{2 7 0} & \mathbf{1 6 0} & \mathbf{2 0} \\ 645 & \mathbf{7 7 5} & \mathbf{8 0 0} & \mathbf{5 0 0} & \mathbf{9 0} \\ \mathbf{2 0 2} & \mathbf{8 0 0} & \mathbf{7 0 0} & >\mathbf{7 0 0} & \mathbf{5 0} \\ \mathbf{6 4 4} & \mathbf{8 0 0} & \mathbf{7 0 0} & \mathbf{5 5 0} & \mathbf{1 8 0} \\ \mathbf{2 8} & \mathbf{9 5 0} & \mathbf{7 0 0} & 400 & \boldsymbol{c} \mathbf{5} \\ \mathbf{R 7 9 0 3} & \mathbf{9 5 0} & \mathbf{1 7 0 0} & >\mathbf{1 7 0 0} & \mathbf{3 0} \\ 9559 & 1370 & \mathbf{4 0 0} & \mathbf{3 5 0} & \mathbf{8 0} \\ \mathbf{9 5 1 7} & 1700 & 1000 & \mathbf{7 5 0} & \mathbf{6 0}\end{array}$

At this point we had to abandon the investigation for a year or so. When we returned to it we found that filtrates provided for us were no longer neutralized in haemolytic or L.V. tests by our old well-tried sera; nor was the new activity due to $\alpha$-toxin. Investigation showed that these new filtrates were derived from type $B$ strains, and that these filtrates were now being used to immunize horses. New sera from these horses were obtained and tested against a new standard Ex949 (230 units) in L.V. and haemolytic tests. Consistent values were obtained in L.V. tests against several type B filtrates (Table 6), suggesting that only one substance affecting L.V. is present in these filtrates; in haemo- 
lytic tests results agreeing with the L.V. results were often obtained; the new 'opalescing' substance $(\beta)$ is probably haemolytic. Against some filtrates, however, haemolytic values considerably less than the $L$.V. values are obtained (Table 7); this may be due to the presence in the filtrates of a haemolysin

Table 6. Comparison of anti- $\alpha$ and anti- $\gamma$ values of sera with their lecithovitellin values against several $\mathbf{C l}$. oedematiens type $B$ filtrates

\begin{tabular}{|c|c|c|c|c|c|c|}
\hline \multirow[b]{2}{*}{ Serum } & \multirow{2}{*}{$\begin{array}{l}\text { Anti- } \alpha \\
\text { value }\end{array}$} & \multicolumn{4}{|c|}{ Lecitho-vitellin values against filtrate } & \multirow{2}{*}{$\begin{array}{l}\text { Anti- } \gamma \\
\text { value }\end{array}$} \\
\hline & & OC91044 & OC271:144 & OC15145 & OC 23445 & \\
\hline Ex 949* & 1200 & $\mathbf{2 3 0}$ & 230 & 230 & 230 & $\mathbf{5 0}$ \\
\hline 2705 & 1650 & 200 & 180 & 160 & 170 & $\mathbf{3}$ \\
\hline T61 & 1650 & 450 & 460 & 400 & 500 & 120 \\
\hline 2209 & 1675 & 240 & $\mathbf{3 3 0}$ & 180 & 200 & 12 \\
\hline $850 \mathrm{~A}$ & 1750 & 1200 & 1300 & 1600 & 1400 & 750 \\
\hline T3 & 6250 & 2150 & 3000 & 3000 & 2000 & 120 \\
\hline
\end{tabular}

antigenically distinct from $\beta$. Filtrates suitable for investigating this point are not yet available. The few sera containing antibody to both $\beta$ - and $\gamma$-toxins (e.g. 850 A) were from horses immunized with filtrates from both types A and B strains. Like $\gamma, \beta$ is a hot-cold lysin.

Table 7. Comparison of lecitho-vitellin, necrotizing and haemolytic values of sera against $\mathrm{Cl}$. oedematiens type $\boldsymbol{B}$ filtrates

\begin{tabular}{lccccc} 
& $\begin{array}{c}\text { Lecitho- } \\
\text { vitellin }\end{array}$ & Necrotizing & \multicolumn{2}{c}{ Haemolytic values against filtrate } \\
\cline { 4 - 6 } Serum & values & values & OC91044 & OC271144 & OK 15145 \\
Ex949 & 230 & 230 & 230 & 230 & 230 \\
T61 & 450 & 300 & 350 & 400 & $<50$ \\
T3 & 2500 & 2000 & 2200 & 2800 & $<50$ \\
2209 & 250 & 230 & 300 & 300 & 90 \\
850 A & 1400 & 1100 & 1300 & 1400 & 1000
\end{tabular}

It may be noticed that the letters assigned to the antigens do not apparently correspond to the order of discovery. This is because we consider that M. G. Macfarlane's description of a lecithinase (almost certainly derived from a type B strain of $\mathrm{Cl}$. oedematiens) is adequate to define this toxin, here therefore assigned the letter $\beta$. The haemolysin $\delta$ was established before the differentiation between $\gamma$ and $\epsilon$ was satisfactorily proved.

At this point we sent samples of filtrates containing $\beta$-and $\gamma$-toxins to Miss M. G. Macfarlane (Lister Institute, Chelsea), who showed that both liberated water-soluble phosphorus from lecithin, and were therefore probably lecithinases; she also confirmed our view that they were antigenically distinct, making use of the method for titrating sera by enzyme inhibition devised for lecithinases by Macfarlane \& Knight (1941).

The fact that $\beta$ and $\gamma$ are lecithinases affords other indicators for them, as in virtue of this activity they might be expected not only to be haemolytic, but to produce a necrotic lesion on intradermal injection, or death on intravenous injection. No filtrate containing $\gamma$-toxin in which all the $\alpha$-toxin had been 
neutralized with sera containing no $\gamma$-antitoxin had any lethal or necrotizing power, presumably because so little active $\gamma$-enzyme was present; several $\beta$-containing filtrates in which the $\alpha$-toxin had been neutralized by sera containing no $\beta$-antitoxin were strong enough to produce a necrotic lesion, but not to kill with certainty. Serum value tests were therefore put up against the standard, and after standing half an hour $0.2 \mathrm{ml}$. of the filtrate-serum mixture was injected intradermally into depilated guinea-pigs. The indicating effect was taken as a necrotic lesion $2 \times 2 \mathrm{~mm}$. developing in 2 days. The serum values so obtained indicate that $\beta$-toxin is necrotizing as well as haemolytic (Table 7).

Some filtrates from type B strains after neutralization of all $\beta$-toxin (as judged by failure of the mixture to affect L.V.) were still haemolytic. This haemolysin $(\zeta)$, though not definitely oxygen-labile, was neutralized to some extent by heterologous sera, and as the serum values against it show (Table 8) is distinct from $\alpha-, \beta-, \gamma-, \delta$ - and $\epsilon$-toxins.

Table 8. Comparison of various values of sera against $\mathrm{Cl}$. oedematiens filtrates, to show independence of $\zeta$-toxin

\begin{tabular}{|c|c|c|c|c|c|c|}
\hline Serum & $\begin{array}{l}\text { Anti- } \alpha \\
\text { value }\end{array}$ & $\begin{array}{c}\text { Anti- } \beta \\
\text { value }\end{array}$ & $\begin{array}{l}\text { Anti- } \gamma \\
\text { value }\end{array}$ & $\begin{array}{l}\text { Anti- } \delta \\
\text { value }\end{array}$ & $\begin{array}{l}\text { Anti- } \epsilon \\
\text { value }\end{array}$ & $\begin{array}{l}\text { Anti- } \zeta \\
\text { value }\end{array}$ \\
\hline 202 & 800 & 0.5 & 700 & 50 & $>700$ & $\mathbf{3 0}$ \\
\hline 644 & 800 & 2 & 700 & 180 & $\mathbf{5 5 0}$ & 140 \\
\hline 9783 & 1000 & 1 & 1100 & 20 & 700 & 70 \\
\hline 9559 & 1370 & 5 & 400 & 80 & $\mathbf{3 5 0}$ & 15 \\
\hline Ex 949 & 1200 & 230 & 50 & 800 & 15 & 1000 \\
\hline T61 & 1650 & 450 & 65 & 10 & 10 & 150 \\
\hline T3 & 6250 & 2500 & 120 & 8 & 12 & 110 \\
\hline $850 \mathrm{~A}$ & 1750 & 1400 & 750 & 220 & 180 & 5000 \\
\hline R7903 & 950 & 20 & 1700 & 30 & $>1700$ & 15 \\
\hline
\end{tabular}

Type C strains ( $\mathrm{Cl}$. bubalorum) grew poorly in the liquid media usually employed for toxin production; on two occasions $\gamma$-toxin appeared to be produced. This finding was confirmed by serum tests on the concentrated filtrates, but further subcultures of these strains failed to yield any toxin. The organism grew well only in meat broth with added meat particles; no toxin was produced in this medium, nor in any medium so far tried has any toxin but $\gamma$ been demonstrated.

\section{Antigenic unity of $\alpha$-toxin of $\mathrm{Cl}$. oedematiens}

We had obtained no evidence that any of our toxins possessed any lethal activity, at any rate in the concentrations normally occurring, except $\alpha$-toxin. A lethal toxin is produced by both types $\mathbf{A}$ and $\mathbf{B}$ strains; on laboratory media, however, type $B$ strains produced much more than type A, and many of the type A strains did not produce enough to be detected. It remained therefore to prove or disprove the antigenic unity of the lethal toxin. Serum tests were therefore set up, using both types $\mathbf{A}$ and $\mathbf{B}$ antisera, against one filtrate derived from $\mathrm{Cl}$. oedematiens type $\mathbf{A}$ and another derived from type $\mathbf{B}$; after standing for $1 \mathrm{hr}$., $0.5 \mathrm{ml}$. of the filtrate-serum mixture was injected subcutaneously into 
mice. The end-point was taken as death of half the mice injected within $48 \mathrm{hr}$. Table 9 shows that within the limits of error of the test there was no difference between the anti-lethal values of the sera against the different filtrates; no evidence is therefore available that $\alpha$-toxin is complex.

Table 9. Comparison of anti-lethal values of sera against $\mathrm{Cl}$. oedematiens type $\boldsymbol{A}$ and type $\boldsymbol{B}$ filtrates, to show antigenic unity of $\alpha$-toxin

\begin{tabular}{|c|c|c|c|c|c|}
\hline \multirow[b]{2}{*}{$\begin{array}{c}\text { Type A } \\
\text { serum }\end{array}$} & \multicolumn{2}{|c|}{ Anti-lethal values against } & & \multicolumn{2}{|c|}{ Anti-lethal values agains } \\
\hline & $\begin{array}{l}\text { Type A } \\
\text { filtrate } \\
\text { AE } 208\end{array}$ & $\begin{array}{l}\text { Type B } \\
\text { filtrate } \\
\text { AE793 }\end{array}$ & $\begin{array}{c}\text { Type B } \\
\text { serum }\end{array}$ & $\begin{array}{l}\text { Type A } \\
\text { filtrate } \\
\text { AE208 }\end{array}$ & $\begin{array}{l}\text { Type B } \\
\text { filtrate } \\
\text { AE793 }\end{array}$ \\
\hline R7870 & 300 & $\mathbf{3 0 0}$ & 2705 & 1700 & 1550 \\
\hline $850 A$ & 1900 & 1550 & 1141 & 750 & 750 \\
\hline R7907 & 1150 & 1000 & 2096 & 1000 & 1000 \\
\hline 97 & 800 & 720 & 2209 & 1700 & 1900 \\
\hline R7869 & 460 & 470 & T3 & 6500 & 6000 \\
\hline R7903 & 850 & 780 & $\mathrm{~T} 61$ & 1700 & 1450 \\
\hline 9559 & 1500 & 1450 & 2184 & 1850 & 1650 \\
\hline
\end{tabular}

Thus there is evidence that including hyaluronidase there are at least seven antigenic substances present in $\mathrm{Cl}$. oedematiens filtrates. The characteristics of those on which we have worked and their distribution among the types are given in Table 10. It is clear that examination for production of $\beta$ and $\gamma$ is adequate for typing.

Table 10. Activities and distribution among types of $\mathrm{Cl}$. oedematiens toxins

Activities of toxin
Lethal, necrotizing
Haemolytic, necrotizing lecithinase
Haemolytic lecithinase
Oxygen-labile haemolysin
Opalescence in lecitho-vitellin; ? pearly layer
Haemolysin

$\begin{array}{cccc}\text { Designation } & \text { Pype A } & \text { Type B } & \text { Type C } \\ \alpha & \overbrace{\text { Typence in }}^{\text {Cl. oedematiens }} \\ \beta & + & + & - \\ \gamma & + & + & - \\ \delta & + & - & ?+ \\ \epsilon & + & - & - \\ \zeta & ?- & + & -\end{array}$

\section{Practical application to typing}

For routine examination strains were grown in $10 \mathrm{ml}$. amounts of Brewer's medium (Brewer, 1940; Hayward, 1943) in test-tubes, the organisms removed by centrifugation or filtration through paper after mixing with a little kieselguhr or 'Hyflo-Supercel' and the filtrate tested as in Table 11.

The results should be read immediately after $1 \mathrm{hr}$ : in the water-bath at $37^{\circ}$ and after not less than $2 \mathrm{hr}$. at room temperature. $\beta$ - and $\gamma$-toxins produce opalescence in L.V. in the water-bath, but are hot-cold haemolysins. If tubes 2 and 4 show no opalescence in the bath, but show a progressive opalescence starting from the bottom of the tube when they are cooled, $\epsilon$ is present. Few of our sera possessed sufficient $\epsilon$-antitoxin to neutralize $\epsilon$ in these tests. If it is desired to avoid trouble with $\epsilon$, dilution of filtrates $1: 4$ will usually prevent its 
action. $\delta$ and $\zeta$ produce rapid haemolysis in the water-bath. No difficulty has arisen in typing all the strains by this method.

A much more convenient way is to carry out typing on plates; the method is similar to that used in the Nagler plate test for $C l$. welchii (Hayward, 1943). The plates are made with Weinberg's V.F. agar containing about $5 \%$ of L.V. After drying for 3-4 hr., half the plate is spread with $0.1 \mathrm{ml}$. serum containing about 200 units $/ \mathrm{ml}$. of $\gamma$-antitoxin or about 20 units $/ \mathrm{ml}$. of $\beta$-antitoxin. The serum is rapidly absorbed by the agar and after about $\frac{1}{2} \mathrm{hr}$. the plate can be inoculated. After 2 days' incubation in the anaerobic jar, the colonies are examined.

Table 11. Arrangement for qualitative determination of toxins present in a $\mathrm{Cl}$. oedematiens filtrate

\begin{tabular}{|c|c|c|c|c|c|c|c|c|c|}
\hline Tube & Contents & & Indicator & & & & sults & & \\
\hline 1 & 1 ml. filtrate + 1 ml. S.A.B. & & & + & + & + & + & + & + \\
\hline 2 & $1 \mathrm{ml}$. filtrate +20 units $\gamma-\mathbf{A} . \mathbf{T}$. & & $0.5 \mathrm{ml}$ & + & + & - & - & $(+)$ & $(+)$ \\
\hline $\mathbf{3}$ & 1 ml. filtrate +10 units $\beta$-A.T. & & L.V. & - & - & + & + & + & + \\
\hline 4 & 1 ml. filtrate $+(20 \gamma+10 \beta)$ units & A.T. & & - & - & - & - & $(+)$ & $(+)$ \\
\hline $\mathbf{5}$ & 1 ml. filtrate + 1 ml. S.A.B. & & & + & $(+)$ & + & $(+)$ & + & $(+)$ \\
\hline 6 & $1 \mathrm{ml}$. filtrate $+1 \mathrm{ml}$. S.A.B. & & & $(+)$ & $(+)$ & $(+)$ & $(+)$ & $(+)$ & $(+)$ \\
\hline 7 & $1 \mathrm{ml}$. filtrate +20 units $\gamma$-A.T. & $+(7 \delta+7 \zeta)$ & $0.5 \mathrm{ml}$. & $(+)$ & $(+)$ & - & - & - & - \\
\hline 8 & $1 \mathrm{ml}$. filtrate +10 units $\beta$-A.T. & units & washed & - & - & $(+)$ & $(+)$ & $(+)$ & $(+)$ \\
\hline 9 & $\begin{array}{r}1 \mathrm{ml} . \text { filtrate }+(20 \gamma+10 \beta) \\
\text { units A.T. }\end{array}$ & A.T. & $\begin{array}{l}\text { horse } \\
\text { red cells }\end{array}$ & - & - & - & - & - & - \\
\hline & & Toxins & esent & $\beta+\zeta$ & $\beta$ & $\gamma+\delta$ & $\gamma$ & $\gamma+\delta+\epsilon$ & $\gamma+\epsilon$ \\
\hline
\end{tabular}

Results. All the type A strains produced $\gamma$-lecithinase; all the type B strains produced $\beta$-lecithinase; no strain produced both $\beta$ and $\gamma$. The appearance of the colonies gave other useful information. Thus the colonies of type $\mathbf{A}$ strains on egg agar were covered with a pearly layer; the lecithinase reaction was well marked and tended to be arranged in concentric rings (Plate 1, fig. 1), whereas the type B colonies (Plate 1, fig. 2) were surrounded by a diffuse lecithinase reaction and showed no pearly layer. Of the forty doubtful strains resembling Cl.oedematiens more closely than any other described anaerobe, butdiffering from it in one or other characteristic, thirty-five produced no lecithinase under our conditions either in liquid culture or on plates, while five produced lecithinases antigenically distinct from both $\beta$ and $\gamma$.

It is of course essential in attempting diagnosis in this way to use sera which do not contain appreciable amounts of antibody to lecithinases for which one is not testing (e.g. $C l$. welchii $\alpha$-toxin); if for instance the oedematiens type $\mathbf{A}$ serum used contains sufficient antibody to $\beta$-toxin, it will inhibit both $\beta$-and $\gamma$ lecithinase reactions; if it contains sufficient antibody to $C l$. welchii $\alpha$-toxin, it will inhibit the reaction due to this toxin also. The more information there is available about the serum values of the sera used, therefore, the more certainly can they be used for typing. 


\section{Comparison with other typing methods}

Fermentation reactions. Scott et al. (1934) separated type A Cl. oedematiens from type B on the ground (among others) that the former fermented glycerol, while the latter did not. There is not much agreement in the literature on the sugars fermented by these organisms, though Turner (1930) in an exhaustive survey of the subject states that on the medium he recommended both types $A$ and $\mathbf{B}$ ferment glucose and maltose, while type $\mathbf{A}$ in addition ferments glycerol. Keppie (1944) on the other hand (admittedly on a somewhat different medium) found that a few strains of type B fermented glycerol, though less vigorously than type A strains.

For our medium we have used: $1 \%$ peptone-water with $0.5 \% \mathrm{NaCl}, 0.25 \%$ agar and $0.5 \%$ of the test sugar, with bromcresol-purple as indicator. The

Table 12. Fermentation reactions of fifty-nine strains of $\mathrm{Cl}$. oedematiens

$$
\begin{aligned}
& \text { Carbohydrate tested }
\end{aligned}
$$

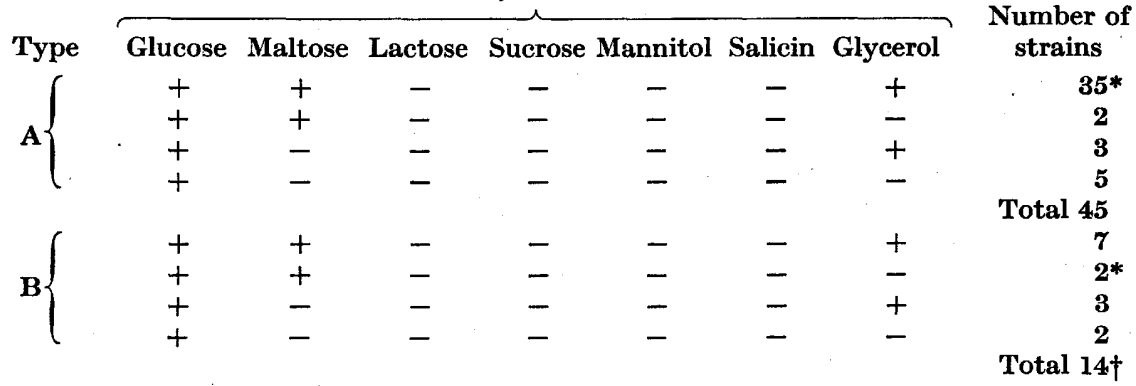

$$
\begin{aligned}
& +=\text { Fermentation with production of acid and gas. } \quad-=\text { No fermentation. } \\
& \text { * 'Typical' strains (criteria of Scott et al. 1934). } \\
& \dagger \text { The remaining two strains could not be obtained pure. }
\end{aligned}
$$

carbohydrates used were: glucose, maltose, lactose, sucrose, mannitol, salicin and glycerol. Anaerobic conditions essential for good growth of $\mathrm{Cl}$. oedematiens, particularly of type $B$ strains, are made possible by the addition of the agar, thus avoiding the use of the anaerobic jar. On this medium some anaerobes bleach the indicator without production of acid; all tubes showing colour change were therefore spot-tested with indicator. No strain certainly $\mathrm{Cl}$. oedematiens produced bleaching, but as this activity is not uncommon among anaerobes and is characteristic of $\mathrm{Cl}$. sporogenes and $\mathrm{Cl}$. histolyticum for example, the test was a convenient screen for examining the unidentified strains, many of which fermented the same sugars as $\mathrm{Cl}$. oedematiens but in addition bleached the indicator in all the other sugars tested. One essential must not be forgotten-the organism must grow well in the medium, or false negatives will be found, as was often the case with type B strains.

Table 12 shows the considerable variation among our strains; though each was consistent in its habits, the results we obtained by no means always agreed with those expected from typing. We are therefore disinclined to rely on fermentation reactions alone for identifying and classifying $\mathrm{Cl}$. oedematiens. 
Grozth and colony form. Type A strains grow more profusely on plates than type B strains, the colonies are denser and slightly raised. Type B strains grow more slowly, require more exacting anaerobic conditions, and produce flatter more filamentous colonies. Differentiation by colony form is, however, very difficult.

Somatic and flagellar antigenic structure (Turner \& Eales, 1943; Keppie, 1944). All $\mathrm{Cl}$. oedematiens strains appear to have two. somatic antigens in common; one of these is shared with $\mathrm{Cl}$. haemolyticum. The thirty-three strains examined by Turner \& Eales (1943) were separable (on the basis of their H-antigenic structure) into eleven groups, seven of which contained only one

Table 13. Lecithinase and pearly layer reactions of $\mathrm{Cl}$. oedematiens and other Clostridium species

\begin{tabular}{|c|c|c|c|c|}
\hline \multirow[b]{2}{*}{ Organism } & \multirow[b]{2}{*}{$\begin{array}{l}\text { Lecithinase } \\
\text { reaction }\end{array}$} & \multicolumn{2}{|c|}{$\begin{array}{l}\text { Inhibition of lecithinase } \\
\text { reaction by sera containing }\end{array}$} & \multirow[b]{2}{*}{ Pearly layer } \\
\hline & & $\begin{array}{l}\text { Cl. oedematiens } \\
\gamma \text {-antitoxin }\end{array}$ & $\begin{array}{l}\text { Cl. oedematiens } \\
\beta \text {-antitoxin }\end{array}$ & \\
\hline Cl. oedematiens Type A & + & + & - & + \\
\hline Type B & + & - & + & - \\
\hline Cl. haemolyticum & + & - & - & - \\
\hline Cl. welchii (all 4 types) & + & - & - & - \\
\hline Cl. sporogenes & + & - & - & + \\
\hline Cl. histolyticum & - & - & - & - \\
\hline Cl. sphenoides & + & - & - & - \\
\hline Cl. sordellii & + & $(+)$ & $(+)$ & + \\
\hline
\end{tabular}

strain. Such antigenic analysis is of fundamental importance; but judging by Turner \& Eales' tables such analysis cannot be used to separate $\mathrm{Cl}$. oedematiens from other genera of Clostridium, nor the three types from one another, without very extensive investigation.

Differentiation of $\mathrm{Cl}$, oedematiens from other lecithinase-producing anaerobes

Several other species of Clostridium produce lecithinase or pearly layer reactions on plates (Table 13). Cl. haemolyticum, regarded by some (e.g. Weinberg, Nativelle \& Prévot, 1937) as a member of the $\mathrm{Cl}$. novyi (Cl. oedematiens) group, produces large amounts of a haemolytic lecithinase, not neutralized in our tube or plate tests by either $C l$. oedematiens $\beta$-or $\gamma$-antitoxins, but readily neutralized by the single anti-haemolyticum serum available. The lecithinase and pearly layer reactions of the remainder present no difficulty as they are not inhibited either by $\beta$-or $\gamma$-antitoxin, but the reactions of $\mathrm{Cl}$. sordellii are of some interest, for after $24 \mathrm{hr}$. incubation they appeared to be slightly inhibited by sera containing either $\beta$-or $\gamma$-antitoxin; no inhibition could be demonstrated at $48 \mathrm{hr}$. After $24 \mathrm{hr}$. as judged by our tests Cl. sordellii might perhaps have been classified as a feebly toxigenic strain of Cl. oedematiens; fortunately, its cultural and biochemical characters differ so greatly from those of $\mathrm{Cl}$. oedematiens that confusion with it is improbable. 


\section{C. L. Oakley, G. H. Warrack and P. H. Clarke}

All the strains available were tested on these plates and gave clear-cut results. In addition it was found possible to identify $\mathrm{Cl}$. oedematiens in impure culture, both by testing the filtrates and by the plate reactions, although if the cultures were heavily contaminated the plates and haemolytic tests were difficult to read.

It must be clearly understood, however, that the tube and plate tests here described provide only indications, however useful, that particular toxins are produced by the strains under test. Proof that a given filtrate contains, say $\beta$-toxin, requires the demonstration that in suitable tests the filtrate is neutralized by $\beta$-antitoxic sera in proportion to their $\beta$-antitoxin content.

Table 14. Comparison of anti- $\beta$ and anti-haemolyticum-lecithinase values of sera in L.V. tests, to show that two Cl. haemolyticum filtrates contain Cl. oedematiens $\beta$-toxin

$\begin{array}{lc}\text { Serum } & \begin{array}{c}\text { Anti- } \beta \text { value against } \\ \text { filtrate OC 23445 }\end{array} \\ 2561 & 31 \\ 2025 & 100 \\ 2147 & 200 \\ \text { T61 } & 500 \\ 850 A & 1600 \\ \text { T3 } & 3250\end{array}$

L.V. value against $\mathrm{Cl}$. haemolyticum filtrate

\begin{tabular}{cc}
\hline OC21846 & OC22846 \\
36 & 36 \\
100 & 125 \\
230 & 230 \\
500 & 500 \\
1600 & 1550 \\
2800 & 2800
\end{tabular}

Proof that a particular filtrate contains a toxin antigenically distinct from $\beta$-toxin, but having similar properties, requires a demonstration that the minimum effective dose of the filtrate against indicators affected by $\beta$-toxin is unaffected by the presence of $\beta$-antitoxin.

These points are well illustrated by $\mathrm{Cl}$. haemolyticum. Two strains of Clostridium, identified by others as $\mathrm{Cl}$. haemolyticum and having the cultural characters of that organism, produce a lecithinase not neutralized in our tube or

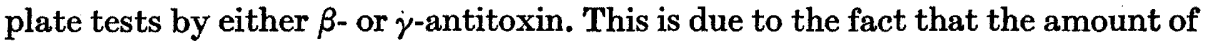
lecithinase produced is far greater than the sera used can neutralize. When the filtrates are diluted considerably, serum-value tests with L.V. as indicator (Table 14) show that the filtrates contain $\beta$-toxin (cf. Sordelli \& Ferrari, quoted by Weinberg et al. 1937). This finding supports the view that Cl. haemolyticum is a member of the $\mathrm{Cl}$. oedematiens group; whether it is a member of type $B$ or a separate type can only be decided when more strains are available for test.

\section{DISCUSSION}

When Scott et al. (1934) divided the 'oedematiens' group into three types, they based their division on source, size, fermentation of glycerol and pathogenicity. It is evident that though their criteria are not as stringent as was at first thought, the conclusions they drew from them are sound; our results support their views and provide type-differentiating criteria of greater stringency. Hayward \& Gray (1946) divide $\mathrm{Cl}$. oedematiens type A into typical and atypical strains on the basis of their fermentation reactions; by their haemolysin test ten out of eleven typical, and eight out of twenty atypical 
strains, were diagnosed as $\mathrm{Cl}$. oedematiens. Putting the matter another way, one typical and twelve atypical strains failed to produce the specific haemolysin. Whether they regard this as a criticism of the haemolysin test is not clear; but if, as we believe, their haemolysin is our $\gamma$-toxin, we are not surprised that they failed to demonstrate it in some instances, as the haemolysin test is so much less sensitive than the L.V. test. They state: 'The atypical $\mathrm{Cl}$. oedematiens includes strains that fermented lactose or sucrose failed to liquefy gelatine or failed to ferment maltose, but resembled $\mathrm{Cl}$. oedematiens in all other morphological, cultural or biochemical characters.' Unfortunately, it is not clear which of the atypical strains gave a positive haemolysin test, or whether lactose or sucrose fermenters were ever diagnosed as $\mathrm{Cl}$. oedematiens by its use. In our hands all our thirty-five typical type $A$ strains and all ten atypical strains (atypical only in that they failed to ferment maltose or glycerol) produced $\gamma$-lecithinase. All the thirty-five strains of unclassified anaerobes that were regarded as distinct from $\mathrm{Cl}$. oedematiens on other grounds (morphology, cultural characteristics) failed to produce $\gamma$-lecithinase; the lecithinases or haemolysins of the few unclassified strains that produced them were antigenically distinct from $\beta-, \gamma-, \delta$ - and $\zeta$-toxins. Most of the unclassified anaerobes fermented glucose, maltose and glycerol; several fermented sucrose and lactose mannitol or salicin. Of our fourteen type $B$ strains only two were typical (Table 12); all fourteen produced $\beta$-lecithinase. Evidently capacity to produce $\beta$ - or $\gamma$-lecithinase is a far more consistent character than capacity to ferment a particular sugar.

We feel that $\mathrm{Cl}$. oedematiens (all types) is best defined as that species of Clostridium possessing Somatic (O) antigens Oed. I or II or both. It is an obligate anaerobe, usually fermenting glucose and maltose and often fermenting glycerol and not fermenting lactose, sucrose, mannitol or salicin; it does not bleach bromcresol-purple. If this definition be accepted $\mathrm{Cl}$. haemolyticum is included in $\mathrm{Cl}$. oedematiens, but determination of its exact position requires the examination of more strains.

The species so defined is readily divisible into three types based on toxin production, type $\mathbf{A}$ producing $\gamma$-toxin, type $\mathbf{B} \beta$, and type $\mathbf{C}$ none. The types thus differentiated show marked internal consistency and agree very well with those based on source, size, cultural characters and pathogenicity. Types based on fermentation reactions or flagellar antigenic analysis alone show no such internal consistency, cut sharply across classifications based on other characters, and are too numerous to be of practical use.

Finally, we would draw attention to the fact that although $\beta$-and $\gamma$-toxins are lecithinases having the same type of enzymatic activity as the $\alpha$-toxin of Cl. welchii (with which they also agree in being activated by calcium ions) they do not attack the same red blood cells as the latter toxin. $\mathrm{Cl}$. oedematiens $\beta$ - and $\gamma$-toxins readily attack horse red cells, which are hardly affected by $C l$. welchii $\alpha$-toxin; sheep red cells, which are readily attacked by $C l$. welchii $\alpha$-toxin, are relatively insensitive to $C l$. oedematiens $\beta$ and $\gamma$. Evidently something is involved in the haemolysis of these different types of red cell beside the enzymatic attack on lecithin. 
Our most grateful thanks are due to Mr A. T. Glenny, F.R.S., for many suggestions and for supplies of sera, to Mr J. G. C. Campbell for filtrates and much information on media, Mr J. C. Macsween and Dr E. W. Todd for some of the filtrates, to Dr Nancy J. Hayward, Dr J. Keppie and Dr J. D. MacLennan for strains, to Dr A. W. Turner for strains, much help and useful information, to Dr M. G. Macfarlane for examining our lecithinases, and to Miss A. M. Brown for flocculation and lethal tests on filtrates and for the substance of Table 9 .

\section{REFERENCES}

Albiston, H. E. (1927). Aust. J. exp. Biol. med. Sci. 4, 113.

Bergey, D. H., Breed, R. S., Murray, E. D. G. \& Hitchen, A. P. (1939). Bergey's Manual of Determinative Bacteriology, 5th ed. Baltimore: Williams and Wilkins.

Brewer, J. H. (1940). J. Bact. 39, 10.

Celarek, J. \& Stetkiewicz, C. (1936). C.R. Soc. Biol., Paris, 122, 143.

Crook, E. M. (1942). Brit. J. exp. Path. 23, 37.

Gildemeister, E. von \& Schlossberger, H. (1932). Z Zbl. Bakt. (1. Abt. Orig.), 126, 527.

Glotowa, E. W., Ostrowskaya, O. A., Ssilanowa, I. W. \& Mrraschewskaya, W. G. (1934). Zbl. Bakt. (1. Abt. Orig.), 132, 57.

Hayward, N. J. (1943). J. Path. Bact. 55, 285.

Hayward, N. J. (1945). Proc. Ass. clin. Path. $1,5$.

Hayward, N. J. \& Gray, J. A. B. (1946). J. Path. Bact. 58, 11.

Keppre, J. (1944). A study of the antigens of $\mathrm{Cl}$. oedematiens and $\mathrm{Cl}$. gigas by in-vivo and in-vitro methods. Ph.D. Thesis, Cambridge.

Kranefeld, F. C. \& Duaenoedin, R. (1933). Ned.-ind. Bl. Diergeneesk. 45, 80.

Kranefeld, F. C. \& DJaenoedin, R. (1936). Ned.-ind. Bl. Diergeneesk. 48, 255.

McClean, D., Rogers, H. J., Williams, B. W. \& Hale, C. W. (1943). Lancet, 1, 355

McClung, L. S., Heidenreich, P. \& Toabe, R. (1946). J. Bact. 50, 715.

MacEwen, A. D. (1931). J. comp. Path. 44, 149.

Macfarlane, M. G. (1942). Biochem. J. 36, Proc. iii.

Macfarlane, M. G. \& KNight, B. C. J. G. (1941) Biochem. J. 35, 884.

Macfarlane, R. G., Oakreey, C. L. \& Anderson, C. G. (1941). J. Path. Bact. 52, 99.

Menk, W. (1929-30). Zbl. Bakt. (1. Abt. Orig.), 115, 401.

Menk, W. (1981-2). Zbl. Bakt. (1. Abt. Orig.), 133, 49.

NAGLer, F. P. O. (1944). Nature, Lond., 153, 496.

NAGLER, F. P. O. (1945). Aust. J. exp. Biol. med. Sci. 23, 59.

NovY, F. G. (1894). Z. Hyg. InfektKr. 17, 209.

ReEd, G. B. \& ORR, J. H. (1941). War Med., Chicago, 1, 493.

Reed, G. B., Orr, J. H. \& Baker, M. C. (1939). Proc. Soc. exp. Biol., N.Y., 42, 620.

ScotT, J. P., Turner, A. W. \& VAwter, L. R. (1934). 12th International Veterinary Congress, p. 168. New York.

Turner, A. W. (1930). Bull. Coun. sci. industr. Res., Aust., no. 46.

Turner, A. W. \& Davesne, J. (1927 a). Ann. Inst. Pasteur, 61, 1078.

Turner, A. W. \& Davesne, J. (1927b). C.R. Soc. Biol., Paris, 97, 921.

Turner, A. W. \& Eales, C. E. (1943). Aust. J. exp. Biol. med. Sci. $21,79$.

Walbum, L. E. \& Reymann, G. C. (1937). J. Path. Bact. 44, 379.

Weinberg, M., Nativelue, R. \& Prévot, A. R. (1937). Les microbes anaérobies. Paris: Masson et Cie.

Weinberg, M. \& Séguin, P. (1915a). C.R. Soc. Biol., Paris, 78, 274.

Weinberg, M. \& SÉguin, P. (1915b). C.R. Soc. Biol., Paris, 78, 507.

Weinberg, M. \& Sḱguin, P. (1915c). C.R. Soc. Biol., Paris, 78, 552.

Zerssler, J. \& RAssfeld, L. (1929). Arch. weiss. prakt. Tierheilk. 59, 419. 
Journal of General Microbiology, Vol. 1, No. 1

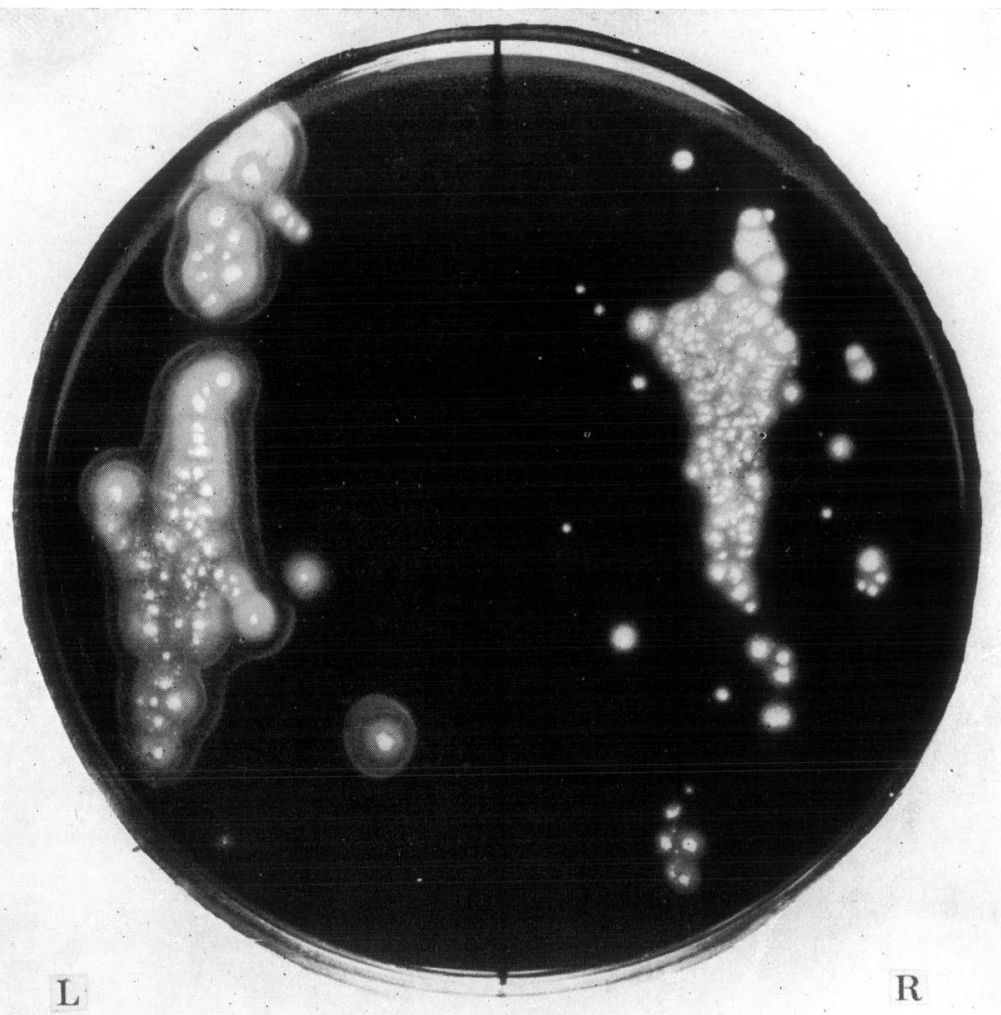

Fig. 1

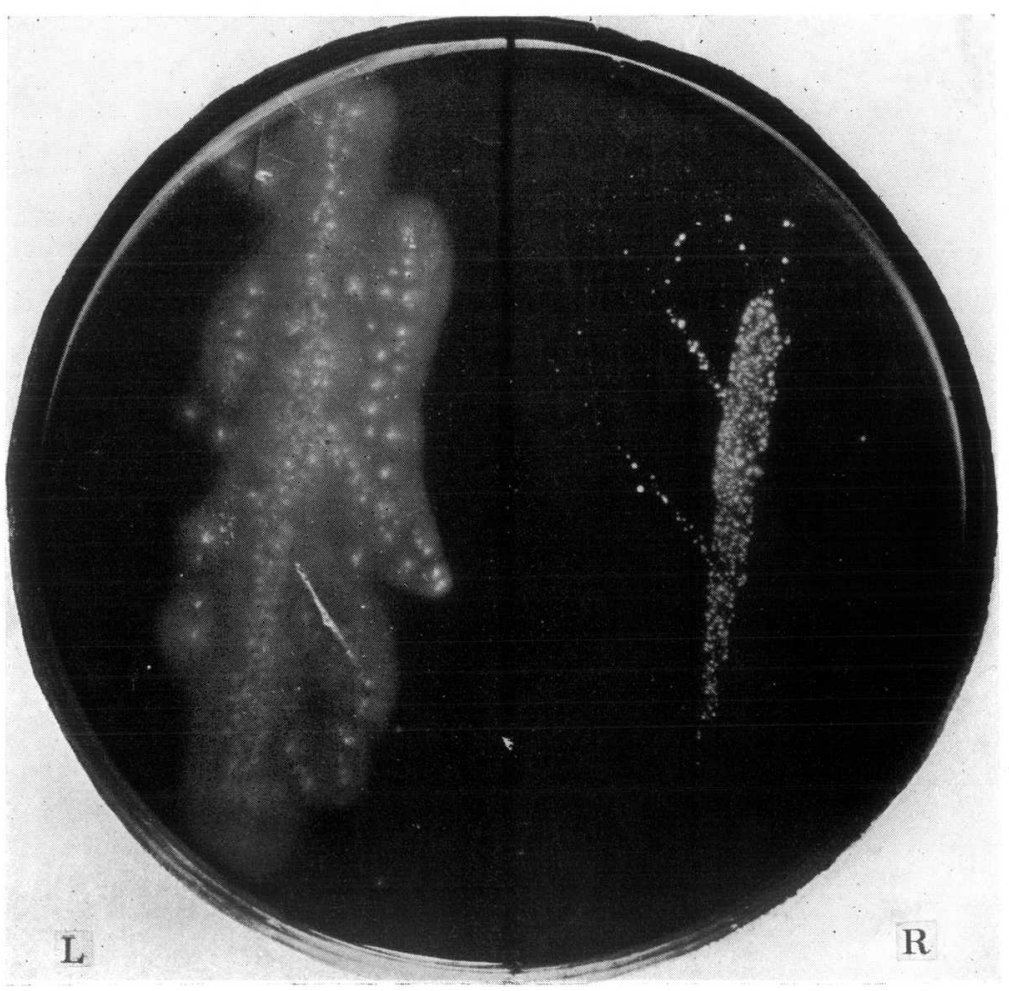

Fig. 2

C. L. Oakley, G. H. Warrack and P. H. Clakke-The toxins of Clostridium oedematiens. Prate 1 


\section{EXPLANATION OF PLATE}

Fig. 1. Cl. oedematiens type A, strain no. 45. Anti- $\gamma$ serum R 7903. Left: culture, no serum. Concentric rings of lecithinase reaction ( $\gamma$-toxin). Right: culture + anti- $\gamma$ serum. Inhibition of lecithinase reaction. Slight haloes due to pearly layer formation ( $\epsilon$-toxin) which is not inhibited.

Fig. 2. Cl. oedematiens type B, strain 'Albiston'. Anti- $\beta$ serum Ex949. Left: culture, no serum. Diffuse lecithinase reaction ( $\beta$-toxin). No concentric rings or pearly layer formation. Right: culture + anti- $\beta$ serum. Inhibition of lecithinase reaction.

(Received 10 September 1946) 